\title{
The Examination of the Views of Primary School Teachers and Preservice Primary Teachers on European Union Citizenship from the point of Different Variables: A Qualitative Study
}

\author{
Sad1k Selman Üner* \\ Karabük University, School of Foreign Languages, Karabük, Turkey
}

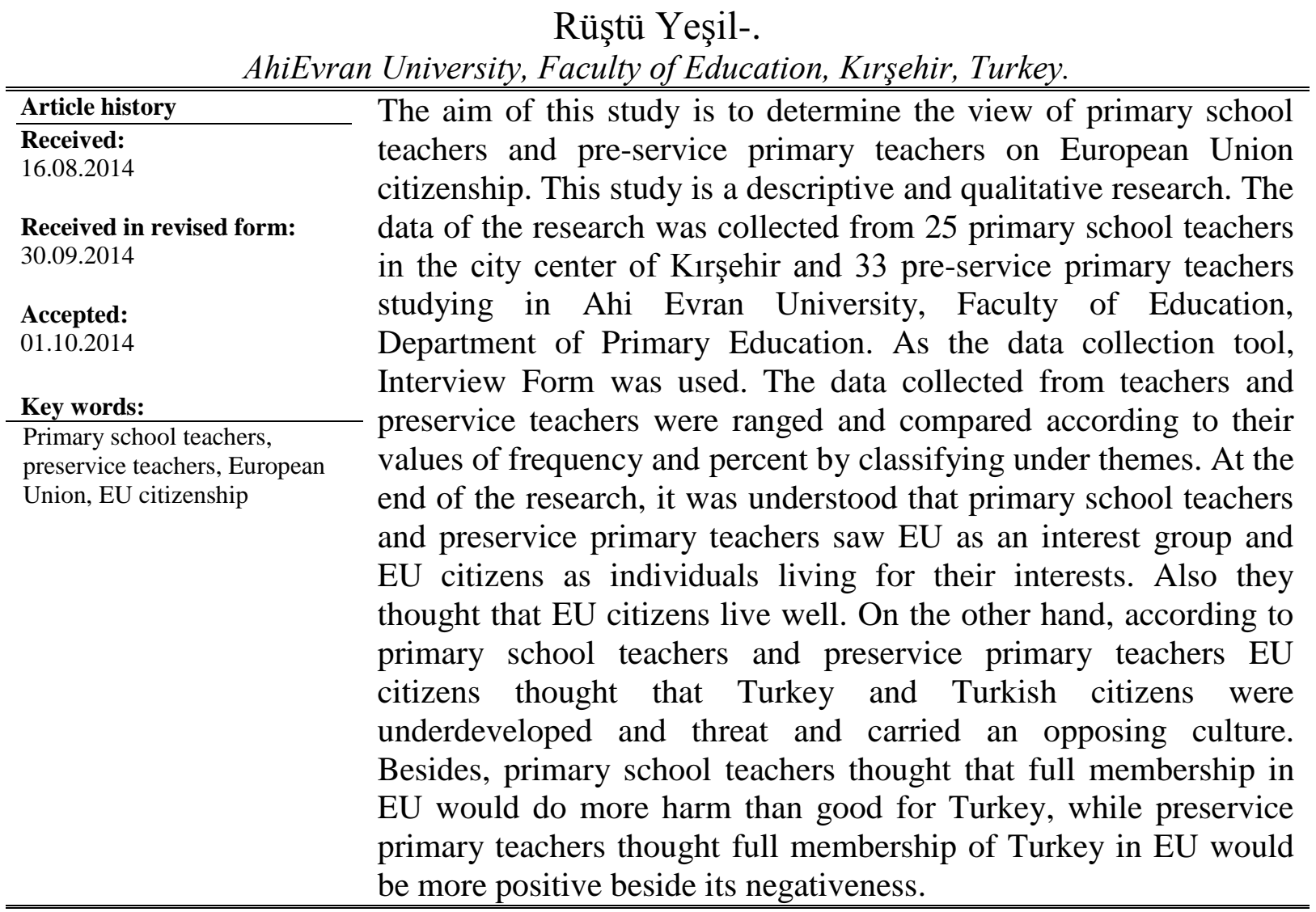

\footnotetext{
* Correspondence: Sadık Selman Üner-Lecturer, Karabük University, School of Foreign Languages, Karabük, Turkey, Email: selmanuner@gmail.com Tel:+905072464427
} 


\section{Introduction}

Although the relation between Turkey and European Union (EU) is seen as an issue of the last century, there was close relations between two societies in the past (Ortayl1, 2008). At the present, this old relation carries on as Turkey's being candidate state in EU. Full membership in EU, which has been discussed as an issue of both internal and foreign politics for years, stays popular in Turkish politics, even if it occasionally fall off the agenda.

EU becomes concrete by the concept of EU citizenship before the society. The concept of "EU citizenship" firstly formalized in Maastricht Treaty. In this treaty, it was stated that "the citizens of member states are also the citizens of EU'. Besides, the rights and liability of EU citizens originated from this citizenship was determined by some treaties and conventions (Kaya, 2013: 142). Thus, the reality can be obviously seen that Turkish citizens will also be EU citizens in case of a probable full membership. In this regard, it can be said that raising consciousness of Turkish citizens about EU and EU citizenship is essential to diminish the problems in the process of target full membership and integration with EU.

The problem of integration with EU is not just a problem of Turkey as a candidate state but also a problem of member states. In some member states, mid-range accepting of Treaty of Maastricht, which is also known as the treaty founding EU, is an indicator of this problem (İnaç, 2005). Besides, in a research done by European Commission in 2012, EU citizens respond the question "Do you feel as a citizen of EU?" yes with rate of $61 \%$, no with rate of $38 \%$ and not know with rate of $1 \%$. Moreover, while the rate of the citizens identifying themselves just with their national identity is $38 \%$, the rate of the ones using their national identity before European identity is $49 \%$, the rate of the ones using European identity before their national identity is $6 \%$ and the rate of the citizens just identifying themselves as European is only 3\% (Standard Eurobarometer 77, 2012: 21-24). That member states come across such a problem may signify that as a member state, Turkey will have similar problems. In this respect, if Turkey wants to be a full member in EU by reason of its government policy, it should take a step in terms of raising consciousness of its citizens about EU and EU citizenship.

As known, raising consciousness is independently an educational issue. Therefore, raising citizens' consciousness about EU citizenship should also be considered as a matter of education. Raising consciousness of citizens about EU citizenship properly may be possible with education. According to Erginer (2006), raising EU citizenship consciousness is definitely or vaguely regarded as a main principal in the objectives part of EU states' education systems. So, education is a phenomenon which should be emphasized to raise EU citizenship awareness.

In Turkey, compulsory basic education starts at primary school. Primary school is a four-yearold period which prepares pupils for the next compulsory eight year. According to most of researchers (Çubukçu \& Gültekin, 2006; İbrahimoğlu, 2009; Sağlam, 2012; Yeşil, 2002), children considerably personalize and gain basic value judgments at this period. So it may be said that the education process raising EU citizenship consciousness of children should necessarily begin at primary school.

Schools, which are planned educational institutions (Doğan, 2012; Potter, 2002; Tezcan, 2012) and teachers, who have influence on students (Güven \& Şahin, 2003; KaramanKepenekçi, 2008), have crucial roles in the process of an education to raise consciousness about EU and EU citizenship within the scope of an official point of view. Thus, primary 
school teachers should have a point of view and carry out their work in parallel with this aim. In this regard, it is important to determine what kind of point of view primary school teachers, who play significant role in citizenship education, have on EU and EU citizenship. This is the main problem of this study.

\section{Aim of the Research}

The main aim of this research is to analyze the view of primary school teachers working in primary schools and preservice primary teachers studying at faculty of education, primary education department on EU and EU citizenship. In this context, primarily following questions are tried to be answered:

(1) What does EU and EU citizenship mean according to primary school teachers and preservice primary teachers?

(2) What are the views of EU states on Turkey and Turkish society according to primary school teachers and preservice primary teachers?

(3) How primary school teachers and preservice primary teachers see EU states in terms of politics, society, economy, culture, respect for human rights and democracy?

(4) What are the views of primary school teachers and preservice primary teachers on full membership of Turkey in EU?

\section{Methodology}

\section{Research Model}

This study is a descriptive and qualitative research. It tried to describe the views of primary school teachers and preservice primary teachers on EU citizenship

\section{Study Sample}

The study sample was comprised of 25 primary school teachers voluntarily filling the interview form and selected randomly from the schools in the city centre of Kirșehir and 33 pre-service primary teachers from $1^{\text {st }}, 2^{\text {nd }}, 3^{\text {rd }}$ and $4^{\text {th }}$ grades studying in Ahi Evran University, Faculty of Education, Department of Primary Education and voluntarily filling the interview form.

\section{Data Collection}

The data of the research was collected by "Interview Form" from the target teachers and preservice teachers groups. It was asked them to express their views in written to take their opinion freely.

\section{Data Collection Tool}

Interview Form: A semi-structured interview from (IF) was developed by the researchers to collect the data of the research. IF has the same questions for both teachers and preservice teachers.

In the process of developing IF, firstly 12 questions were prepared by taking account of the main and sub problems of the research; these questions were examined in terms of structure and content by the researchers with two different specialists and linguists and the questions were restructured in accordance with the suggestions. Finally, IF was composed of instruction 
and five open-ended questions. Within the framework of these questions, the views of the primary school teachers and preservice primary teachers on EU and EU citizenship were tried to be determined. The questions in IF are below:

(1) What does European Union and European Union citizenship mean in your opinion? Please explain.

(2) Do you think how European Union states and citizens see Turkey and its people? Please explain.

(3) What do you think of European Union states in terms of politics, society, economy, culture, respect for human rights and democracy? Please explain.

(4) Do you think should Turkey be a full member in European Union? Why?

(5) What do you think about the probability of Turkey's full membership in European Union? Why?

\section{Data Analysis and Interpretation}

While the data collected by IF was being analyzed, main themes were formed for each question. Results of researches in the literature (Alkan, 2013; Altunay, 2012; Başbay \& Doğan, 2004; Dinç, 2009; Özuğurlu, 2009; The German Marshall Fund of the United States, 2011) and the main and sub problems of the research was helpful to form the themes. The researchers arrived a consensus while naming the themes. The themes stated in the research are below:

Primary school teachers' and preservice primary teachers';

(1) Describing EU and EU citizenship

(2) Thoughts about the view of EU states on Turkey and its people

(3) Thoughts about EU in terms of politics, society, economy, culture, respect for human rights and democracy

(4) Thoughts about the necessity for full membership of Turkey in EU

(5) Thoughts about the probability of Turkey's full membership in EU

Then, the forms collected from the participants were examined by content analysis method and sub themes were formed under the main themes. Results of researches in the literature and the concepts and matters in related researches were tried to be considered while forming the sub themes. While forming the sub themes, firstly the researchers examined the forms on their own and formed sub themes. Then, they discussed on sub themes and reached a consensus on the same sub themes. The sub themes were formed by difference for each main theme. The first main theme has 11, the second one has 9, the third main theme has 7, the third one has 6 and the fifth main theme has 8 sub themes.

After that, the answers of the teachers and preservice teachers were evaluated under coherent sub themes. The thoughts of the teachers and preservice teachers were tried to be stated in more than one sub themes in case of including different sub themes. Frequency and percentage were used in evaluating the sub themes. Determining the percentage, the number of the participants for both groups was considered ( 25 teachers, 33 preservice teachers). The findings were shown in tables. Afterwards, the rates of the sub themes were ranged from more to less according to their choosing intensity and the subthemes were explained by using the frequency rates and percentages.

Lastly, the findings in tables were interpreted. The answers of the participants were quoted 
while interpreting the sub themes. In these quotes, the primary school teachers and preservice primary teachers were enumerated for hiding their names and they were called with these numbers during the evaluation.

\section{Findings}

The findings got at the end of the research are shown in the tables below and explained:

\section{Findings within the Main Theme of "EU and EU Citizenship Descriptions of Primary School Teachers and Preservice Primary Teachers"}

The data of the first theme was collected and analyzed by asking primary school teachers and preservice primary teachers "What does European Union and European Union citizenship mean in your opinion". After the analysis, the range of the descriptions under 11 sub themes is given in Table 1.

Table 1. The thoughts of primary school teachers and preservice primary teachers about EU and EU citizenship

\begin{tabular}{|c|c|c|c|c|c|}
\hline \multirow[t]{2}{*}{ Theme } & \multirow[t]{2}{*}{ Sub themes } & \multicolumn{2}{|c|}{ Teacher } & \multicolumn{2}{|c|}{$\begin{array}{l}\text { Preservice } \\
\text { Teacher }\end{array}$} \\
\hline & & f & $\%$ & $\mathbf{f}$ & $\%$ \\
\hline \multirow{11}{*}{ 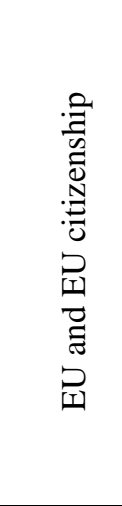 } & Liberty & 5 & 20 & 7 & 21.21 \\
\hline & Welfare & 9 & 36 & 14 & 42.42 \\
\hline & $\begin{array}{l}\text { Democratic/Knowing their rights and } \\
\text { liabilities }\end{array}$ & 4 & 16 & 12 & 36.36 \\
\hline & Self-disciplined/Successful & 2 & 8 & 3 & 9.09 \\
\hline & Interest Group & 9 & 36 & 14 & 42.42 \\
\hline & Christian Association & 8 & 32 & 2 & 6.06 \\
\hline & Trade and Travel Liberalization & 5 & 20 & 6 & 18.18 \\
\hline & Consumption Culture & 2 & 8 & 0 & 0 \\
\hline & Tolerant/Respectful & 3 & 12 & 8 & 24.24 \\
\hline & Colonialism & 2 & 8 & 1 & 3.03 \\
\hline & Nothing/Insignificant & 2 & 8 & 4 & 12.12 \\
\hline
\end{tabular}

In Table 1, thoughts of primary school teachers and preservice primary teachers about EU and EU citizenship were shown. According to the thoughts of primary school teachers about EU and EU citizenship, the sub themes of "interest group" and "welfare" were chosen at most with the rate of $36 \%$. Preservice primary teachers also chose these sub themes at most with the rate of $42.42 \%$. Primary school teachers at the least chose the sub themes of "selfdisciplined-successful", "consumption culture", "colonialism" and nothing/insignificant" with the rate of $2 \%$. Preservice primary teachers chose the sub themes of "colonialism" with the rate of $3.03 \%$ and "Christian association" with the rate of $6.06 \%$ at the least. Besides, there was no thought of preservice primary teachers about the sub theme of "consumption culture".

Some of the answers of the teachers (T2, T3, T4, T7, T8, T11, T13, T16, T19) about the sub theme of "welfare" are given. "European Union means more liberal, more prosperous and more democratic society." explained Teacher-2 (T2). "European Union means having a high quality of life, in my opinion. EU citizenship means living well" said T4. "A person who is liberal, knows his/her rights, gives importance to production and consumption, is more tactful, more tolerant, rich, conformist and a bit arrogant, looks up other people (except USA) from the point of wealth and liberty, makes judgment about these people in this context 
and thinks to exploit these people and many countries." expressed T11.

Some of the thoughts of the teachers (T3, T5, T6, T12, T14, T15, T17, T18, T24) about the sub theme of "interest group" are below. "European Union and its citizenship is European states' living concertedly toward mutual interests from the points of notably politics, economy, culture, religion and transportation." told T5. "European Union is a community which people of the same religion and similar races founded for their mutual interests. This union was founded for economical, political and cultural privileges and superiorities of these people. European Union citizenship symbolizes the privilege these people want to have around the world under this roof. It means having an unmerited prestige and privilege through EU citizenship." explained T15. "It means living in the states that are economically interdependent and being a part of society which is materialist and depends on working, producing and consuming." said T24.

The answers of the preservice teachers (PT1, PT3, PT4, PT5, PT9, PT11, PT15, PT19, PT23, PT24, PT27, PT29, PT32, PT33) under the sub theme of "welfare" were randomly chosen and given below. "European Union and its citizenship mean an occidental life. It absolutely has negative and positive sides. It is a kind of society which has freedom of thought and a prosperous life, treasures human but looks out for itself." stated Preservice Teacher-9 (PT9). "It means having a more modern life style, providing a democratic life, being liberal and developed, including multi-culture and prioritizing equality and justice." expressed PT23. "It is a developed citizenship which gives importance to human rights, democracy and rule of law and doesn't discriminate people according to their society, politics and ethnicity." said PT33.

Some of the views of preservice teachers (PT1, PT2, PT8, PT9, PT10, PT13, PT14, PT15, PT16, PT18, PT21, PT22, PT25, PT28) on the sub theme of "interest group" are given. In this context, "It means nothing. Because this system called European Union is both capitalist and self-righteous against other nations. Although its aim was initially seen as maintaining peace among European states, this union was abused by being deviated from its aim." stated PT2. "European Union is a constitution which looks after the interests of member states. Its citizenship provides great convenience like visa-free travel among these states." expressed PT10. "In my opinion, EU is an association of European states for their economic interests, that is, a sort of commercial treaty. The point they regard is interests." explained PT13.

\section{Findings within the Main Theme of "The Thoughts of Primary School Teachers and Preservice Primary Teachers about the View of EU States on Turkey and Its People”}

The data of the second main theme was collected and analyzed by asking primary school teachers and preservice primary teachers "Do you think how European Union states and citizens see Turkey and its people? Please explain.”. After analyzing, the range of the views under 9 sub themes is given in Table 2. 
Table 2. The thoughts of EU states about Turkey and its people according to primary school teachers and preservice primary teachers

\begin{tabular}{|c|c|c|c|c|c|}
\hline \multirow{2}{*}{ Theme } & \multirow{2}{*}{ Sub Themes } & \multicolumn{2}{|c|}{ Teacher } & \multicolumn{2}{|c|}{$\begin{array}{l}\text { Preservice } \\
\text { Teacher }\end{array}$} \\
\hline & & $\mathbf{f}$ & $\%$ & $\mathbf{f}$ & $\%$ \\
\hline \multirow{9}{*}{ 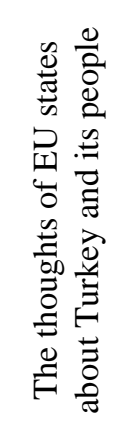 } & Reactionist & 5 & 20 & 2 & 6.06 \\
\hline & Muslim/An opposing religion or culture & 9 & 36 & 12 & 36.36 \\
\hline & Inconvenience & 1 & 4 & 2 & 6.06 \\
\hline & Underdeveloped/ Poor for EU & 10 & 40 & 16 & 48.48 \\
\hline & Enemy/Threat & 7 & 28 & 9 & 27.27 \\
\hline & Interest & 4 & 16 & 3 & 9.09 \\
\hline & $\begin{array}{l}\text { Disrespectful against human rights and } \\
\text { democracy }\end{array}$ & 4 & 16 & 6 & 18.18 \\
\hline & Undisciplined/Lawless & 2 & 8 & 0 & 0 \\
\hline & No idea & 1 & 4 & 2 & 6.06 \\
\hline
\end{tabular}

In Table 2, the thoughts of primary school teachers and preservice primary teachers about the view of EU states and citizens on Turkey and its people were shown. As seen, primary school teachers thought that the view of EU states on Turkey and its people was at most seen as "underdeveloped/poor for EU" with the rate of $40 \%$, "Muslim/An opposing religion or culture" with the rate of $36 \%$ and "enemy/threat" with the rate of $28 \%$. This range is the same for preservice teachers. They chose "underdeveloped/poor for EU" with the rate of $48.48 \%$, "Muslim/An opposing religion or culture" with the rate of $36.36 \%$ and "enemy/threat" with the rate of $27.27 \%$ at most. In this context, primary school teachers chose "inconvenience" with $4 \%$ and "undisciplined/lawless" with $8 \%$ at the least. $4 \%$ of teachers expressed that they had "no idea". None of preservice teachers chose the sub theme of "undisciplined/lawless". Preservice teachers chose the sub theme of "inconvenience" at the least. $6.06 \%$ of them also said that they had "no idea".

Some of the thoughts of teachers (T1, T2, T5, T6, T8, T10, T13, T16, T19, T21) are randomly given. "I think that they see us as second-class people and society." said T1. "Like other societies, EU and its citizens think that science is very developed in west and eastern countries are underdeveloped from the point of education, health, society and culture; based on this, including many culturally and socially different nations, Turkey is seen as inequable and poor for EU." stated T5. "They think that we more uncivilized and underdeveloped than them." said T16.

Some of the views of preservice teachers (PT2, PT4, PT5, PT9, PT11, PT13, PT15, PT17, PT19, PT20, PT23, PT25, PT26, PT27, PT29, PT31) about the sub theme of "underdeveloped/poor for EU" are stated. "Turkey is a puppet in the eyes of European states. They can easily use Turkey in internal and foreign policy. They also won't want Turkey as a member in EU. In which country is there police murders, corruption and constitutional disruption? World media sees and think about these things. EU citizens also don't want Turkey as a member in EU." told PT4. "They see Turkey and its people less developed. They think that so. Because Turkey is a developing country in many aspects." expressed PT11. "Turkish people and society are not liked. They are seen as less developed than EU states." explained PT29. 


\section{Findings within the Main Theme of "The Thoughts of Primary School Teachers and Preservice Primary Teachers about EU States in terms of Politics, Society, Economy, Culture, Respect for Human Rights and Democracy"}

The data of the third sub theme was collected and analyzed by asking primary school teachers and preservice primary teachers "What do you think of European Union states in terms of politics, society, economy, culture, respect for human rights and democracy? Please explain.". After analyzing, the range of the thoughts under 7 sub themes is shown in Table 3.

Table 3. The Thoughts of Primary School Teachers and Preservice Primary Teachers about EU States in terms of Politics, Society, Economy, Culture, Respect for Human Rights and Democracy

\begin{tabular}{|c|c|c|c|c|c|}
\hline \multirow[t]{2}{*}{ Theme } & \multirow[t]{2}{*}{ Sub Themes } & \multicolumn{2}{|c|}{ Teacher } & \multicolumn{2}{|c|}{$\begin{array}{l}\text { Preservice } \\
\text { Teacher }\end{array}$} \\
\hline & & $\mathbf{f}$ & $\%$ & $\mathbf{f}$ & $\%$ \\
\hline \multirow{7}{*}{ 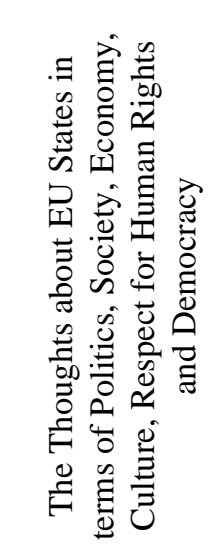 } & Developed & 8 & 32 & 24 & 72.72 \\
\hline & Underdeveloped & 4 & 16 & 3 & 9.09 \\
\hline & Different for each state & 2 & 8 & 3 & 9.09 \\
\hline & Looking out for itself & 13 & 52 & 10 & 30.30 \\
\hline & $\begin{array}{lll}\begin{array}{l}\text { Socially } \\
\text { collapsing }\end{array} & \text { and culturally } \\
\end{array}$ & 5 & 20 & 4 & 12.12 \\
\hline & Brutal capitalist & 2 & 8 & 0 & 0 \\
\hline & Unsure/No idea & 5 & 20 & 1 & 3.03 \\
\hline
\end{tabular}

In Table 3, the thoughts of primary school teachers and preservice primary teachers about EU states in terms of politics, society, economy, culture, respect for human rights and democracy were given. According to this, primary school teachers saw EU as "looking out for itself" with the rate of $52 \%$ and "developed" with the rate of $32 \%$. Primary school teachers mostly chose the sub theme of "developed" with $72.72 \%$ and "looking out for itself" with the rate of 30.30 while expressing their thoughts about EU. While primary school teachers chose the sub themes of "different for each state" and "brutal capitalist" with the rate of $2 \%$ at the least, preservice primary teachers chose the sub themes of "underdeveloped" and "different for each state". None of the preservice teachers expressed their idea about the sub theme of "brutal capitalist". Also, $20 \%$ of the teachers and $3.03 \%$ of the preservice teachers said that they were "unsure" or had "no idea".

Some of the thoughts of teachers (T6, T9, T11, T13, T14, T15, T18, T20, T21, T22, T23, T24, T25) about the sub theme of "looking out for itself" are shown. "European Union states are a law unto themselves. I don't agree that they respect for human rights." implied T6. "European Union is economically in good condition. They have high living standards. It only looks out for its citizens in terms of human rights and democracy." mentioned T13. "They are very democratic if it suits their book. They are selfish. They lack of moral value." said T20.

Some of the view of preservice teachers (PT1, PT2, PT3, PT4, PT5, PT6, PT8, PT9, PT11, PT12, PT14, PT15, PT16, PT17, PT19, PT20, PT22, PT25, PT26, PT28, PT29, РT30, РT31, $\mathrm{PT} 33)$ on the sub theme of "developed are given. In this context, "European people are more 
developed than our country in terms of respect for human rights and democracy. They respect individuals and their rights." explained PT3. "These concepts correspond with these states and their citizens. They are developed in all aspects. They rate people because of being human in these countries. This thought cause the other developments." said PT20. "They are prosperous, developed and prim." told PT33.

\section{Findings within the Main Theme of "The Thoughts of Primary School Teachers and Preservice Primary Teachers about the Necessity of Turkey's Full Membership in $\boldsymbol{E} \boldsymbol{U}^{\prime}$}

The data of the forth main theme was collected and analyzed by asking primary school teachers and preservice primary teachers "Do you think should Turkey be a full member in European Union? Why?". After analyzing, the range of the thoughts under 6 sub themes is given in Table 4.

Table 4. The thoughts of primary school teachers and preservice primary teachers about the necessity of Turkey's full membership in EU

\begin{tabular}{|c|c|c|c|c|c|}
\hline \multirow[t]{2}{*}{ Theme } & \multirow[t]{2}{*}{ Sub Themes } & \multicolumn{2}{|c|}{ Teacher } & \multicolumn{2}{|c|}{$\begin{array}{l}\text { Preservice } \\
\text { Teacher }\end{array}$} \\
\hline & & $\mathbf{f}$ & $\%$ & $\mathbf{f}$ & $\%$ \\
\hline \multirow{6}{*}{ 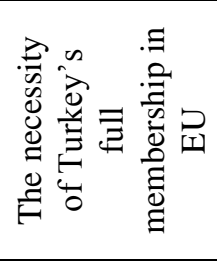 } & Advantageous & 10 & 40 & 20 & 60.60 \\
\hline & Unnecessary & 6 & 24 & 5 & 15.15 \\
\hline & Disadvantage & 12 & 48 & 14 & 42.42 \\
\hline & Lost its old significance & 2 & 8 & 0 & 0 \\
\hline & They need us & 3 & 12 & 0 & 0 \\
\hline & Unsure/No idea & 3 & 12 & 4 & 12.12 \\
\hline
\end{tabular}

In Table 4, the thoughts of primary school teachers and preservice primary teachers about the necessity of Turkey's full membership in EU were given. Within this scope, primary school teachers mostly expressed their opinions about the necessity of Turkey's full membership in EU under the sub themes of "disadvantage" with the rate of $48 \%$ and "advantageous" with $40 \%$. Preservice primary teachers expressed their opinions under the sub themes of "advantageous" with the rate of $60.60 \%$ and "disadvantage" with the rate of $42.42 \%$. While the sub themes chosen by primary school teachers at the least were "lost its old significance" with the rate of $8 \%$ and "they need us" with $12 \%$, none of the preservice primary teachers chose these sub themes. Besides, $12 \%$ of primary school teachers and $12.12 \%$ of preservice primary teachers expressed that they were "unsure" or had "no idea".

Some of the answers of teachers (T3, T6, T7, T10, T14, T15, T16, T17, T18, T19, T21, T24) under the sub theme of "disadvantage" are shown. According to this, "I find it advantageous because of providing a life style in compliance with European standards. But I find it disadvantageous due to the fact that we will compensate our values and change our culture." explained T3. "I think Turkey's full membership in EU has more harm than good. Turkey can develop much more without this membership. They want many compromises and enforcements before membership. This is very disadvantageous for us. If we develop more and have a strong economy, they will try to make us their member. Otherwise, we may be supposed to give Cyprus or make law about same-sex marriage." said T15. "I think we shouldn't be member. We can come across with the same cultural degeneration." told T24.

Some of the thoughts of preservice teachers (PT1, PT2, PT3, PT4, PT5, PT6, PT8, PT9, PT11, PT12, PT14, PT15, PT16, PT17, PT19, PT20, PT22, PT25, PT26, PT28, PT29, РT30, 
PT31, PT33) under the sub theme of "advantageous" are shown. In this context, "Full membership in EU will absolutely be very advantageous for Turkey. Turkey will develop from the points of politics, society, economy and human rights. There are some disadvantages of membership beyond advantages. It may cause some familial, more generally cultural degeneration." expressed PT8. "It has good and bad sides. Good sides: Every people will have the same rights. Bad sides: We will capitulate about our national and religious values." mentioned PT19. "Turkey's full membership in EU will be an advantage for Turkey's being decisive in world politics. Also, adopting EU frameworks throughout Turkey will make a contribution to development in the education, health and economy. But, Turkey's being full member in EU may cause some degeneration in Turkey's traditions and language." stated PT28.

\section{Findings within the Main Theme of "The Thoughts of Primary School Teachers and Preservice Primary Teachers about the Probability of Turkey's Full Membership in EU”}

The data of the fifth main theme was collected and analyzed by asking primary school teachers and preservice primary teachers "What do you think about the probability of Turkey's full membership in European Union? Why?". After analyzing, the views under 8 sub themes are given in Table 5.

Table 5. The thoughts of primary school teachers and preservice primary teachers about the probability of Turkey's full membership in EU

\begin{tabular}{|c|c|c|c|c|c|}
\hline \multirow[t]{2}{*}{ Theme } & \multirow[t]{2}{*}{ Sub Themes } & \multicolumn{2}{|c|}{ Teacher } & \multicolumn{2}{|c|}{$\begin{array}{l}\text { Preservice } \\
\text { Teacher }\end{array}$} \\
\hline & & f & $\%$ & f & $\%$ \\
\hline \multirow{8}{*}{ 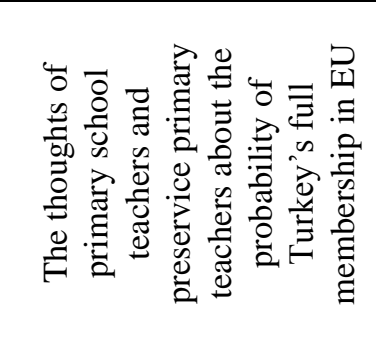 } & Delayed & 8 & 32 & 7 & 21.21 \\
\hline & Can't be member & 10 & 40 & 4 & 12.12 \\
\hline & Turkey withdraws & 3 & 12 & 0 & 0 \\
\hline & Possible by fulfilling the conditions & 2 & 8 & 6 & 18.18 \\
\hline & Minimal chance & 4 & 16 & 4 & 12.12 \\
\hline & EU accept when it needs & 2 & 8 & 4 & 12.12 \\
\hline & EU don't want Turkey & 4 & 16 & 9 & 27.27 \\
\hline & Unsure & 4 & 16 & 3 & 9.09 \\
\hline
\end{tabular}

In Table 5, the views of primary school teachers and preservice primary teachers about the probability of Turkey's full membership in EU were given. In this context, while primary school teachers mostly expressed their opinion under the sub themes of "can't be member" with the rate of $40 \%$ and "delayed" with $32 \%$, preservice primary teachers expressed their views under the sub themes of "EU don't want Turkey with the rate of $27 \%$ and "delayed" with 21.21 at most. Within this scope, the least chosen sub themes by primary school teachers were "possible by fulfilling the conditions" and "EU accept when it needs" with the rate of $8 \%$, preservice primary teachers expressed their opinions under the sub themes of "can't be member", "minimal chance" and "EU accept when it needs" with the rate of $12.12 \%$. None of the preservice teachers expressed their views under the sub theme of "Turkey withdraws". Also $16 \%$ of teachers and $9.09 \%$ of preservice teachers stated that they were "unsure".

Some of the answers of teachers (T1, T6, T13, T15, T17, T20, T22, T23, T24, T25) under the sub theme of "can't be member" are given. "I think that Turkey's full membership in EU is impossible. Because, Turkey is significantly underdeveloped in terms of economy, society and human rights and EU states don't want Turkey as a member of EU. For example, Greece." 
explained T1. "In my opinion, Turkey will not have a chance of being full member in EU, they don't accept. Because, EU practices double standards. They will find pretexts and difficulties. They told us to give Cyprus, found a Kurdish state and make concessions to Kurds, etc." said T15. "They don't accept Turkey as a member in EU. Because we are Muslims." expressed $\mathrm{T} 24$.

Some of the views of preservice teachers (PT3, PT5, PT7, PT10, PT17, PT20, PT25, PT29, PT32) under the sub theme of "EU don't want Turkey" are shown below. In this context, "I think that they won't accept Turkey as a full member in EU. They don't want a Muslim country in Christian association. Or they make an effort until they change us." told PT7. "Republic of Turkey is the continuation of Ottomans. They proselytized Islam throughout the three continents. We defeated them in Balkan Wars and Crusades. All of the Christians are filled with the hate of Islam and Turks. They will never accept us and we had better give it up." stated PT10. "Turkey is a country including 70 million people. I don't expect that EU will accept Turkey as a full member. Because, if there is visa-free travel, this population will immigrate Europe. This will not be welcomed by EU states. I think, Turkey shouldn't be a member of EU. It should found "Turan Union" with Turkic states in the Middle East." expressed PT32.

\section{Conclusion and Discussion}

The results found after examining the views of primary school teachers and preservice primary teachers on EU and EU citizenship are given below by being discussed.

1. Primary school teachers and preservice primary teachers think that EU is an association that was founded by the states looking out for their interests and EU citizens are the people who behave according to this. Also, they express that EU and EU citizens are prosperous.

That primary school teachers and preservice primary teachers mostly pointed out welfare level has parallels with the other researches (Alkan, 2013; Altunay, 2012; Dinç, 2009; Eurobarometer 74, 2010; The German Marshall Fund of the United States, 2011). But, in this regard, the interesting point is the views that EU is an interest group and EU citizens just only look out for themselves. According to Ortaylı (2008), the political unity between the EU states, which were at war for ages, is not only a situation after the foundation of EU, but also there had been before. European states didn't only found a unity after Second World War; but they had founded same unities in spite of being at hundreds of wars throughout history. Therefore, just as there were European states, which initially made war against each other and then they founded unities but finally broke it; the permanence of the current unity may not be guaranteed. These unsteady unities between European countries may cause the result that primary school teachers and preservice primary teachers think that EU and its citizens are interest groups looking out for themselves.

2. Primary school teachers and preservice primary teachers think that EU and its citizens see Turkey and its people as poor and underdeveloped for being a member of EU, carrying an opposing culture and religion and an enemy or a threat. But some researches in the literature show a bit different results from this study. In the study by The German Marshall Fund of the United States (2011), EU states indicated that Turkey has an adequate economy to be a member of EU; besides, Turkey's membership in EU will make a great contribution to the economy of EU and even become effective to maintain peace in the Middle East. However, it can be seen that EU states have a prejudice against Turkey. In a study by Boğaziçi University European Studies Research Center (2009), it was determined that EU citizens pointed out 
cultural criteria rather than political and economical criteria while expressing their opinions about Turkey. According to this, most of the negative thoughts of EU citizens about Turkey were composed of cultural factors with the rate of $45.6 \%$; while political factors had a rate of $29.7 \%$ and economical factors had $20.7 \%$. In this context, the thoughts of primary school teachers and preservice primary teachers are in accord with the reality in terms of religious and cultural aspects but irrelevant with the reality from the point of economy and politics.

3. Primary school teachers think that EU states look out for themselves in terms of politics, society, economy, culture, respect for human rights and democracy. There are relevant interpretations above about looking out for themselves in terms of politics, society and economy. But from the point of respect for human rights and democracy, an analysis can't be properly done whether EU institutionally looks out for its interests in this regard, or not. However, the national behaviors of EU states may cause some thoughts in this point. For instance, France's deporting Gypsies, double standards examples of France against Muslims and repressive approaches of some European governments against Muslims show that EU dissembles especially about human rights and democracy. For this reason, primary school teacher may think that EU looks out its interests in terms of politics, society, economy, culture, respect for human rights and democracy.

That preservice primary teachers see EU as developed in terms of politics, society, economy, culture, respect for human rights and democracy may derive from the fact that recently EU is tried to be shown as if it undertakes both regional and global missions and it is a developed constitution. For example, because of winning Nobel Peace Prize in 2012 (The Nobel Foundation, 2014), trying to be held a mediatory position in Ukraine crisis in 2014, finding Turkey unjust about human rights and democracy in European Court of Human Rights and due to the fact that these event have a broad repercussion in press and social media, EU may be seen as developed by preservice primary teachers, who follow the internet and social media much more efficiently.

4. While primary school teachers think that full membership of Turkey in EU will do more harm than good, preservice primary teachers think vice versa. In fact, when the answers of both groups are analyzed, it can be obviously seen that most of both teachers and preservice teachers see it both an advantage and a disadvantage. As the related researches are analyzed, The German Marshall Fund of the United States (2011) determined that the attitude of Turkish citizens about EU was positive with the rate of $48 \%$ in 2011 . But, it was stated that this attitude was at the rate of $73 \%$ in 2004 and it generally showed a falling tendency until 2011. According to the report of Eurobarometer 74 (2010), it was seen that in 2010, $42 \%$ of Turkish people thought that full membership of Turkey in EU would be positive. In the same research, it was found that the rate of the people thinking negative was $32 \%$. When the data of the researches in 2004 and 2010 are compared, it is clear that the rate of the ones thinking positive showed a falling tendency from $71 \%$ to $48 \%$, while the rate of the ones thinking negative showed an upward tendency from $9 \%$ to $32 \%$. The common result in two researches is that the number of Turkish people thinking positive about EU is almost the same with the number of the ones thinking negative. As seen, in this research, teachers and preservice teachers explain their opinions in this direction.

5. While primary school teachers express that Turkey will not be a member of EU because of political, social, economical, cultural and religious reasons, preservice primary teachers indicate that Turkey will not be a member of EU because of the prejudice of EU against Turkey. 
The answer of teachers and preservice teachers show that although the views of both groups about the future of Turkey membership in EU differ from each other, basically the common idea of them is that Turkey won't be a full member of EU under no circumstances. While teachers say that Turkey will meet some internal and foreign obstacles in the process of EU membership, in addition to this, preservice teachers especially imply that EU won't accept Turkey as a full member. Beside the obstacles derived from EU, teachers also tell that Turkey will not fulfil the required criteria for being a full member. But, preservice teachers express that EU will not accept Turkey as a full member in no way. In this regard, both groups mostly indicate cultural and religious reasons. Thus, that lots of states, which are more underdeveloped than Turkey in many points, were admitted to full membership in EU and Turkey has been delayed because of some excuses may cause that generally Turkish people and especially teachers and preservice teachers think that Turkey will not be a full member of EU.

In the study, researching the views of EU states on the full membership of Turkey, by Akşit, Şenyuva and Üstün (2009), it is seen that these states cannot reach a consensus in this regard. On the one hand there are countries leaning towards the full membership of Turkey like Spain and supporting it in certain circumstances like Romania, Bulgaria and Sweden; on the other hand there are countries which are in opposition to Turkey's full membership on all occasions like France, Australia, Greece and South Cyprus and which express both positive and negative opinions in this context like Italy. Also, the membership of Turkey is not a popular agenda and don't call public's attention in some countries like Check Republic, Poland and Belgium. Briefly, it can't be right to say that there is a consensus in EU states about the full membership of Turkey. However, the reasons of the ones who don't support it are mostly based on cultural, religious and historical facts. For the full membership of Turkey, the number of the states which regard human rights and democracy, which EU primarily stipulates for membership, is very few comparing with the number of the other group.

\section{Suggestions}

In consideration of the discussions and the results of the research, these may be suggested to contribute to develop a right point of view about EU and EU citizenship:

1. Conferences, panels and symposiums reflecting an official point of view on the process of full membership in EU, its advantages and disadvantages may be used to raise the consciousness of primary school teachers and preservice primary teachers about EU and EU citizenship.

2. The activities by which teachers and preservice teachers can observe EU states, their life styles, and cultures on the spot may be featured.

3. In the curriculum of primary and high schools, there may be the contents and activities which aim to introduce the EU policy of Turkey and socio-cultural aspects of EU states. Also it can be suggested that there may be courses including the information about the EU policy and membership process of Turkey in the curriculum of faculties of education.

4. The personal and institutional interactions between Turkey and EU states can be increased by popularizing the student and teacher exchange programs within EU.

5. This research was applied to primary school teachers and preservice primary teachers. Similar researches in the same context may be applied to teachers in elementary and high 
schools, preservice teachers who will probably work in these grades and instructors in universities.

\section{Acknowledgement}

This article was generated from the master's thesis "The Examination of the Views of Primary School Teachers and Pre-service Primary Teachers on European Union Citizenship from the point of Different Variables".

\section{References}

Akşit, S., Şenyuva, Ö. \& Üstün, Ç. (2009). The view of European Union states on the membership of Turkey [Avrupa Birliği ülkelerinden Türkiye'nin üyeliğine bakış]. METU Center for European Studies, Ankara.

Alkan, M. N. (2013). European Union perception of university students in Turkey [Türkiye'deki üniversite öğrencilerinin Avrupa Birliği algısı]. Konrad-AdenauerStiftung, Ankara, Turkey.

Altunay, E. (2012). Investigation of predictor variables of European Union identity in education institutions. Unpublished dissertation. Ege University Social Sciences Institute, İzmir, Turkey.

Başbay, A. \& Doğan, N. (2004). Conceptions of teachers related to effect of European Union membership adaptation process on our education system. Ege Educational Journal [Ege Ë̆itim Dergisi], 5(2), 35-52.

Boğaziçi University European Studies Research Center (2009). The view of Europeans on Turkey as a prospective member of Europe and Europeanization problems of Turkey [Avrupalıların Müstakbel Bir Avrupa Üyesi Olarak Türkiye'ye Bakışları ve Türkiye'nin Avrupalılaşma Sorunları]. http://hakanyilmaz.info/yahoo_site_admin/assets/docs/BUCES-AID-UAMOpinionPoll-Sunus-Turkce-v03.356161957.pdf (Access: 04.05.2014).

Çubukçu, Z. \& Gültekin, M. (2006). Social skills that need to be gained by primary school students. Journal of Social Sciences of the Turkish World [Bilig Türk Dünyası Sosyal Bilimler Dergisi], 37: 155-174.

Dinç, E. (2009). The view of preservice teachers on Europe and European citizenship. I. International European Union, Democracy, Citizenship and Citizenship Education Symposium, Uşak University European Union Education Application and Research Center: 201-207.

Doğan, İ. (2012). Educational sociology [Eğitim sosyolojisi]. Ankara: Nobel Publishing.

Erden, M. (2007). Introduction to educational sciences [Eğitim bilimlerine giriş]. Ankara: Arkadaş Press.

Erginer, A. (2006). European Union education systems [Avrupa birliği eğitim sistemleri]. Ankara: Pegem Akademi Publishing.

Eurobarometer 74 (2010). Public opinion in the European Union: Turkey. http://ec.europa.eu/public_opinion/archives/eb/eb74/eb74_tr_tr_nat.pdf (Access: 07.05.2014).

Güven, S. \& Şahin, İ.F. (2003). Qualities and the problems of teachers of citizenship and human rights course: Erzincan city sample. Eastern Geographical Review [Doğu Coğrafya Dergisi], 8(10): 213-226.

İbrahimoğlu, Z. (2009). Active citizenship definitions of preservice primary teachers and the role providing social studies course to raise active citizen. I. International European Union, Democracy, Citizenship and Citizenship Education Symposium, Uşak 
University European Union Education Application and Research

Center: 437-443.

İnaç, H. (2005). Identity problems of Turkey during the European Union integration process

[AB'ye entegrasyon sürecinde Türkiye'nin kimlik problemleri]. Ankara: Adres Publishing,

Karaman-Kepenekçi, Y. (2008). Human rights and citizenship for educators [Eğitimciler için insan hakları ve vatandaşlık]. Ankara: Ekinoks Press.

Kaya, A. (2013). European Union citizenship. (Editor: A. Kaya et al). Introduction to European Union: History, institutions, policies [Avrupa Birliği'ne giriş: Tarih, kurumlar, politikalar] (p.133-148). İstanbul: İstanbul Bilgi University Publishing.

Kırşehir National Education Directorate (2014). 2012-2013 Academic Year National Education Statistics, http://kirsehir.meb.gov.tr/arge/upl/dokumanlar/haber/istatistik2013/index.html (Access: 07.04.2014).

Ortaylı, İ. (2008). Europe and us [Avrupa ve biz]. İstanbul: Turkey İş Bank Culture Publications.

Özuğurlu, M. B. (2009). Perception of university students about European Union and European citizenship concepts [Üniversite gençliğinin Avrupa Birliği'ni ve Avrupa vatandaşlığı fikrini algılaması]. I. International European Union, Democracy, Citizenship and Citizenship Education Symposium, Uşak University European Union Education Application and Research Center: 320-324.

Potter, J. (2002). The challenge of education for active citizenship. Education and Training, 44(2), 57-66.

Sağlam, H. İ. (2012). An investigation on primary school teachers' perceptions of effective citizenship proficiency by certain variables. Journal of Social Studies Education Research, 3(2): 71-85.

Standard Eurobarometer 77 (Spring, 2012). TNS Opinion \& Social http://ec.europa.eu/public_opinion/archives/eb/eb77/eb77_value_en.pdf

Tezcan, M. (2012). Educational sociology [Eğitim sosyolojisi]. Ankara: Anı Publishing.

The German Marshall Fund of United States. (2011). Transatlantic trends 11. http://www.gmfus.org/archives/transatlantic-trends-2011/ (Access: 06.05.2014).

The Nobel Foundation (2014). The Nobel Peace Prize 2012. http://www.nobelprize.org/nobel_prizes/peace/laureates/2012/ (Access: 18.05.2014).

Yeşil, R. (2002). Human rights and democracy education in school and family [Okul ve ailede insan hakları ve demokrasi eğitimi]. Ankara: Nobel Press. 